\title{
ANALISIS FUNGSI DAN NILAI-NILAI BUDAYA MITOS EMBUNG PUNTIQ
}

\author{
${ }^{1}$ Samsul Hakim, ${ }^{2}$ Roby Mandalika Waluyan \\ ${ }^{1,2}$ Pendidikan Bahasa dan Sastra Indonesia, Universitas Muhammadiyah Mataram, Indonesia \\ ${ }^{1}$ samsul.hakim@gmail.com, ${ }^{2}$ robywaluyan22@gmail.com
}

\begin{abstract}
INFO ARTIKEL
ABSTRAK

Riwayat Artikel:

Diterima : 22-11-2018

Disetujui : 22-01-2019

\section{Kata Kunci:}

Mitos, Nilai Budaya,

Embung Puntiq.

\section{Keywords:}

Myths; Cultural Values,

Embunt Puntiq.

Abstrak: Penelitian ini mengkaji tenntang fungsi dan nilai-nilai budayamitos Embung Puntiq pada masyarakat sasak di desa sengkrang Kabupaten Lombok Tengah. Mitos Embung Puntiq adalah sebuah makam yang dikeramatkan oleh masyarakat sasak. Di samping makan tersebut terdapat sebuah sumur masyarakat setempat menyebutnya lingkoq emas. Jadi mitos Embung Puntiq adalah sebuah makam yang dikeramatkan oleh masyarakat sasak karena dipercayai memiliki banyak pengaruh bagi masyarakat. Misalnya; ketika tanaman rusak, warga datang mengambil air di embung atau air sumur yang berada di makam tersebut. Ketika ada warga yang sakit namun tidak kunjung sembuh meski telah berobat ke dokter, juga dating mengambil air sebagai pengobatan Embung Puntiq menunjukan fungsi yang meluputi; 1) sebagai bentuk hiburan 2) sebagai alat pengesahan pernata dan lembaga kebudayaan; 3) sebagai alat pendidikan alat; 4) sebagai alat pemaksa dan pengawas agar norma-norma masyarakat dipatuhi anggota kolektifnya. Sedangkan hasil analisis nilai-nilaidan budaya meliputi; nilai relig, nilai kebersamaan, nilai social, nilai pendidikan dan nilai ekonomi.
\end{abstract} Abstract: This study examines the function and values of the budayamitos of the beak
Puntiq in Sasak society in the village of central Lombok Regency. The mythical
Puntiq myth is a tomb that is sacred to Sasak people. In addition to the meal there is
a well local people call Lingkoq gold. So the myth of the bbly Puntiq is a tomb that is
sacred to the Sasak people because it is believed to have many influences for society.
For example When the plant is damaged, residents come to take water in the bbly or
water wells that are in the tomb. When there is a sick citizen but do not heal despite
having treatment to the doctor, also dating taking water as a medicine bbly Puntiq
shows the function that is in the; 1) as a form of entertainment 2) as a means of
ratification of pernata and cultural institutions; 3 ) As a tool education tool; 4) as a tool
of wearers and supervisors so that the norms of society are adhered to by its members
of its library. While the results of the analysis of values and culture include;
Reliability, value of togetherness, social value, educational value and economic value.

\section{A. LATAR BELAKANG}

Mitos Embung Puntiq adalah mitos yang hidup pada masyarakat sasak di desa sengkerang Kabupaten Lombok Tengah. Mitos Embung Puntiq sampai saat ini masih diyakini oleh masyarakat yang tinggal di wilayah desa sengkerang. Mitos ini dikenal dari zaman dulu hingga sampai saat ini masyarakat masih mengenalnya dengan baik dan tempat tersebut masih ada di ingatan mereka.
Pada awalnya, keberadaan Embung Puntiq dari wasiat mas panji pengedeng yang memiliki sifat mulia. Mas panji pengedeng meninggal akibat peperangan, sebelum meninggal dia berwasiat agar jinazahnya tidak dibawa pulang, tidak dibakar ataupunt di kuburkan. Agar kelak bila ada anak cucu yang ingin berziarah, mereka bebas dari perasaan enggan. Biarlah agar semua orang dapat berkunjung di tempat ini. Bila mereka hendak dating berziarah hendaklah mereka berkeliling sekurang-kurangnya 
tiga, tijuh ataupun Sembilan kali. Maksudnya supaya anak cucu yang beragama islam meniatkan diri belajar tawaf di Mekkah serta mewasiatkan untuk dating sekurang-kurangnya dua kali dalam ssetahun. Yaitu menjelang musim penghujan, ketika bibit padi diisiapkan dan kedua sewaktu menanam padi telah selesai.

Setelah mas panji pengedeng menyelesaikan wasiatnya diapun meninggal dan anehnya jenazahnya menghilang, diceritakan hanyalah berkas darah yang tersisa di tempat berbaringya. Sehingga diceritankan bahwa bekas darah panji pengedeng itulah dibuat sebuah makam. Makam tersebut dahulunya adalah perkebunan pisang yang dalam bahasa sasaknya kebon puntiq dan terdapat sumur sehingga makam tersebut sampai sekarang dinamakan makam Embung Puntiq.

Jadi mitso Embung Puntiq adalah sebuah makam yang dikeramatkan oleh masyarakat sasakk karena dipercaayai memiliki banyak pengaruh bagi masyarakat sasak. Misalnya; ketika tanaman disawah rusak, warga datng peperangan, sebelum meninggal dia berwasiat agar jinazahnya tidak dibawa pulang, tidak dibakar ataupunt di kuburkan. Agar kelak bila ada anak cucu yang ingin berziarah, mereka bebas dari perasaan enggan. Biarlah agar semua orang dapat berkunjung di tempat ini. Bila mereka hendak dating berziarah hendaklah mereka berkeliling sekurang-kurangnya tiga, tijuh ataupun Sembilan kali. Maksudnya supaya anak cucu yang beragama islam meniatkan diri belajar mengambil air di embung atau air sumur yang berada di dekat makam tersebut. Ketika ada warga yang sakit namun tidak kunjung sembuh meski telah berobat ke dokter, juga datang mengambil air sebagai pengobatan. Begitu juga bagi orang yang belum mendapatkan jodoh serta pasangan yang belum mendapatkan keturunan.

Saxby (Nurgiantoro 2002 : 173) mengatakan bahwa mitos muncul pada tiap masyarakat atau kultur berkaitan dengan kebutuhan masyarakat yang bersangkutan untuk menjawab berbagai persoalan yang tidak diketahuinya. Mitsos hadir untuk memenuhi dan memuaaskan rasa ingin tau, memenuhi kebutuhan religi yang dipergunakan untuk mengatur kehidupan.

Oleh karena itu, miitos dipandang sebagai suatu keramat, kemudian menjadi cerita rakyat kemudian menjadi cerita rakyat yang diwariskan secara turun- temurun. Terlepas dari adanya orang yang mempertanyakan atau menolak kebenarannya, mitos tetap saja dijadikan sebagai tempat pencaarian yang bersifat spiritual terhadap masalah kebenaran dan kehidupan.

Akan tetapi perkembangan ilmu pengetahuan dan teknologi menyebabkan orang lebih berpikir kkedepan dan melupakan kisah-kisah masa lalu. Oleh karena itu penelitian ini dimaksudkan agar penilitian satra lisan sebagai hasil budaya khusunya mitos ceerita rakkyat tidak hilang dari masyarakat akibat perkembangan teknologi, karena pada kenyataanya mitos embung puntiiq masih dipercayai oleh sebagian masyarakat sasak.

Sesungguhnya istilah pembicaraan kualititaf ini mubazir. Dipihak lain juga mengatakan metode kualitatif ini sudah diuraikan sebagai subbab tersendiri. Dalam analisis ke dua, metode yang dianggap lebih tepat bukan semata-mata kualitatif itu sendiri melainkan kualitatif interpretif. Dengan kalimat lain, metode kualitatif sebagai ilmu-ilmu social, humaniora khussnya kajian budaya, perlu diperluas secara penafsiran, secara khas bersifat tekstual sebagai kualitatif interpretif. budaya khusunya mitos ceerita rakkyat tidak hilang dari masyarakat akibat perkembangan teknologi, karena pada kenyataanya mitos embung puntiiq

Seperti yang sudah dibicarakan di atas, kualitatif adalah metode intensitas kualitas, nilai-nilai, dibedakan dengan kualitatif, metode sebagai pengukuran dalam bentuk angka, jumlah sedangkan interpretative adalah penafsiran. Penelitian kualitatif didominasi oleh masalah-masalah mental manusoa, yang dengan sendirinya tidak dapat dikategorikan secara matematis, tetapi sebagai penelitian ilmiah, maka cara lerja yang dimaksudkan harus secara rinci (Ratna, 2003:305-311)

Metode kualitatif interpretative digunakan oleh peneliti untuk menjadi focus terkait dengan analisis fungsi dan nilai-nilai budaya mitos Embung Puntiq pada masyarakat sasak di desa Sengkareng Kabupaten Lombok Tengah.

Adapun proses atau langkah akerja analistis data dalam penelitian ini meliputi langkah-langkah sebagai beikut:

\section{Identifakasi Data}

Dalam kamus bahasa Indonesia identiffikasi adalah penentuan penepatan identitas sesseoranag, bednda dan sebagainya, sejalan dengan pendapt di 
atas indentifikasi ,merupakan proses menentukan atau menetapkan bagian yang ditemukan dalam data yang dikaitkan masalah yanf timekukan. (Mahsun, 2014:110)

\section{Klasifikasi}

Klasifikasi merupakan suatu prosses yang bersifat alamiah untuk menampilkan mengelompokkan sesuai dengan pengalaman manusia. Gagasan-gagasan yang dikenal melalui pengalaman disusun dengan system yang teratur. Dengan demikian klafikasi yang dilakukan dalam penelitian ini merupakan jalan untuk menjangkau bermacam subjek kendala suatu penelitian atau kelompok merepkan suatu subjek ke dalam hubungan yang akan masuk akal berdasarkan suatu sisstem yang dalam suatu konteks logis.

\section{Interpretasi}

Interpretasi pada dasarnya sama dengan hermeneutic (Yunani) yang berarti menafsirkan, dalam hal ini Dengan demikian klafikasi yang dilakukan dalam penelitian ini merupakan jalan untuk menjangkau bermacam subjek kendala suatu penelitian atau kelompok merepkan suatu subjek ke dalam hubungan

\section{B. METODE PENELITIAN}

\section{Rancangan Penelitian}

Penelitian ini menggunakan pendekatan kualitatif dengan metode deskriptif. Pemdelatan kualitatid adalah suatu proses penelitian dan pemahaman yang berdasarkan pada metodologi yang menyelidiki suatu fenomena social dan masalah manusia, sedangkan metode deskriptif adalah penelitian yang berusha mendeskripsikan gejala, peristiwa, lejadian yan g terjadi saaat sekatang. (Noor, 2011 : 33-34)

\section{Data dan Sumber Data}

Data dalam penelitian ini beberapa mitos Embung Puntiq pada masyarakat sasak di desa sengkerang Kabupaten Lombok Tengah.

Sumber data dalam penelitian ini adalah orangorang yang dipandang mengetahui tenntang Embung Puntiq pada masyarakat sasak di desa sengkerang Kabupaten Lombok Tengah.

Mengingat banyaknya jumlah populasi, maka penelitian ini dibatasi sample penelitian dengan menggunakan teknik purposive sampling. Pemerintah Kabupaten Lombok Tengah adalah agar lebih mempromosikan Komplekks pemakaman Embung Puntiq sebagai wisata religi Kabupaten Lombok Tengah, sehingga penelitian tenntag mitos Embung Puntiq semakin diminati oleh peneliti. Selain itu, keberadaan kompleks pemakaman tersebut lebih mendapat sorotan dari masyarakat.

Peneliti menyadari bahwa hasil penelitian ini masih jauh dari sempurna karena itulah peneliti mengharapkan agar hasil penelitian ini dapat menjadi pemicu untuk mengembangkan penelitian tentang mitos. Mitos cerita Embung Puntiq hendaknya dilestarikan, karena mitos merupakan asset Purposive sampling adalah untuk menentukan sample Para petani di desa sengkerang berhubungan erat dengan mitos Embung Ountiq setiao musim padi telah tiba ataupun setelah selesaii menanam padi para petani bahkan ketika tanaman rusak meraka penelitian dengan beberapa pertimbangan tertentu yang bertujuan agar data yang deperoleh nantinya bias lebih repsentatif (Sugiyono, 2014)

\section{Metode pengumpulan data}

Untuk memperoleh data yang diperlukan maka peneliti menggunakan beberapa metode dalam mpengumpulan data. Metode pengumpulan data yang digunakan dalam penelitian ini sebagai berikut:

\section{a. Metode Observasi}

Metode observasi adalah peninjauan secara cermat, memperhatikan sesuatu dengan menggunakan panca indra. Jadi mengobservasi dapat dilakukan melalaui penglihatan, penciuman, pendengaran, peraba dan pengecap. Apa yang dikatakan ini adalah pengamatan langsung (Arikunto, 2006:84)

Metode observasi dilakukan untuk menjau secara dcermat dan melakukan pengamatan terhadap objek atau lokasi yang akan menjadi temmpat penelitian. Metode observasi ini digunakan penelitian berlangsung di desa Sengkerang Kabupaten Lombok Tengah.

\section{b. Metode Dokumentasi}

Metode dokumentasi yaitu mencari data mengenai hal-hal atau variable merupakan catatan transkip, buku, surat kabar, majalah, dan lain sebagainya.

Dengan menggunakan metode ini peneliti dapat mengabil dokumen berupa foto ketika sedang melakukan penelitian. 


\section{c. Metode Wawancara}

Metode wawancara merupakan cara yang ditempuh dalam proses pengumpulan data dengan cara peneliti langsung bertatap mukadan melakukan percakapan informan (Mahsun, 2013:110). Dengan menggunakan metode ini peneliti mengetahui fungsi, dan nilai-nilai budaya mitos Embung Puntiq

Metode wawancara digunakan untuk mendapatkan data asli Embung Puntiq. Yang diturunkan oleh beberapa informan atau penutur yabg beradadi daerah penelitian, serta peneliti dengan mudah menyimak tentang mitos tersebut.

\section{Metode Analisis Data}

Sesuai dengan jenis penelitian, yaitu kualitatif, maka jenis datanya adalah kualitatif. Dengan demikian maka metode yang tepat adalah kualitatif itu ssendiri. ,e;ihat perkembangan ilmu social juga, ilmu humaniora khususnya kajian budaya, maka semata-mata metode kualitatif dianggap belum cukup. Oleh karena itu, metode kualitatif diperluas menjadi interpretif, hermeneotika, dan versthen. Dengan kalimat lain ada persamaan, yaitu interpretif itu sesndiri. Dalam kehiduoan praktis, bahkan masyarakat ilmiah menganggap ketiga itu sama, dalam analisis Metode observasi dilakukan untuk menjau secara dcermat dan melakukan pengamatan terhadap objek atau lokasi yang akan menjadi temmpat penelitian. Jadi mengobservasi dapat dilakukan melalaui penglihatan, penciuman, pendengaran, peraba dan pengecap. Apa yang dikatakan

\section{HASIL DAN PEMBAHASAN}

\section{Deskripsi Hasil Penelitian Mitos Embung Puntiq}

Alkisah, pada suatu desa yang bernama Bayan, tinggallah sebuah keluarga. Sang ayah bernama Panji Bayan Ullah Petung Bayan, sedangkan anaknya bernama Panji Bayan Sangge. Suatu hari tatkala Panji Bayan Sangge masih kanak-kanak, entah karena apa, ia pergi meninggalkan desa kelahirannya untuk mengembara.

Setelah melewati berbagai lembah dan bukit, akhirnya Panji Bayan Sangge tiba di sebuah daerah yang bernama Batu Dendeng. Hutang memang harus dibayar, takdir juga harus dijalani. Singkat cerita, di Batu Dendeng Panji Bayan Sangge dijadikan anak angkat oleh sepasang suami-isteri yang tidak mempunyai anak, bernama Inaq Bangkol dan Amaq Bangkol. Ia dianggap dan diperlakukan seperti anak kandungnya sendiri. Ia tidak merasakan kejanggalan apapun juga. Inaq dan Amaq Bangkol dianggap sebagai orang tuanya sendiri. Mereka saling mengasihi, mencintai dan pada segi-segi tertentu saling menghormati. Hari berganti minggu, bulan demi bulan datang silih berganti, tahun demi tahun menyusul, akhirnya Panji Payan Sangge meningkat dewasa. Ia telah menjadi seorang pemuda.

Pada suatu hari ia mengemukakan niatnya kepada Inaq Bangkol untuk menggarap sebuah ladang. Setelah membuat petak ladang dan memagarinya, maka oleh Inaq Bangkol diberikan beberapa bibit tanaman seperti: jagung, berbagai jenis kacang, gandum dan lain-lain tanaman yang pantas atau cocok untuk di taman di ladang.

Demikianlah, setelah beberapa waktu bibit yang diberikan oleh Inaq Bangkol ditanam, bibit-bibit itu tumbuh dengan suburnya. Panji Bayan Sangge merasa sangat gembira. Ia semakin giat mengurus ladang.

Beberapa minggu kemudian, pemandangan pada ladang itu telah berwarna-warni oleh berbagai jenis bunga. Tampaknya tak lama lagi semua tanaman akan berbuah. Itu berarti semua pengorbanan dan jerih payah Panji Bayan Sangge tidak akan sia-sia.

"Ibu, tadi pagi ketika ananda ke ladang, semua bunga tanaman itu telah hilang. Kalau dikatakan itu adalah perbuatan babi atau kera, rasanya tak mungkin. Karena tak satu pun tangkainya yang patah. Karena itu ananda bermaksud untuk mengadakan pengintaian. Barangkali ada tangantangan jahil yang sengaja merusak tanaman kita."

"Baik, bunda setuju dengan rencana itu. Jagalah dirimu baik-baik dan jangan sampai terjadi hal-hal yang tidak kita inginkan. Bertindaklah dengan jujur dan tidak boleh berbuat kasar kepada siapapun. Segala persoalan pasti dapat diselesaikan dengan baik. Dengar dan perhatikan nasihat bunda ini." Demikian kata-kata Inaq Bangkol kepada Panji Bayan Sangge sesaat sebelum berangkat ke ladang.

Pada malam harinya Panji Bayan Sangge mulai melakukan pengintaian. Dengan cermat ia mengawasi ladangnya. Semua sudut ladang tak lepas dari perhatiannya. Namun, sudah hampir semalam suntuk tak ada sesuatu pun yang mencurigakan. Hening, sepi, tak ada sesuatu atau seseorang yang mendatangi ladangnya.

Saat menjelang fajar, ketika Panji Bayan Sangge sedang bergulat dengan hebatnya menahan kantuk, tiba-tiba dari jurusan yang tak dapat dilihatnya, sembilan orang bidadari turun dari langit dan dengan asyiknya mengisap dan merusak bunga tanaman itu. Pengisapan dan perusakan bunga terus 
dilakukan dari satu pohon ke pohon yang lain. Melihat tingkah bidadari itu hati Panji Bayan Sangge menjadi gemas.

"Akan kuapakan perempuan-perempuan yang merusak tanamanku ini? Bila aku biarkan pasti bunga-bunga ini akan habis. Apakah hasilku nanti? Ah, lebih baik kutangkap saja barang seorang," pikirnya. Dengan sigap, Panji Bayan Sangge menangkap salah seorang dari bidadari itu. Sang bidadari mengadakan perlawanan sekuat tenaga. Namun apa daya, Panji Bayan Sangge memiliki tenaga yang jauh lebih besar. Melihat peristiwa yang tak diinginkan itu, bidadari yang lain menjadi ketakutan dan melarikan diri. Panji Bayan Sangge segera membawa bidadari yang tertangkap itu pulang ke rumahnya.

Setelah tiba di rumah, ia mencari dan memberitahu Inaq Bangkol, "Ibu, dialah yang merusak tanaman kita di ladang. Hukuman apakah yang akan kita berikan kepadanya?"

"anakku, bila bidadari ini merusak tanaman kita di ladang, ibu hanya berdoa, memohon kepada Yang Maha Kuasa, semoga ananda dijodohkan dengan dia, janganlah dihukum. Dia akan kujadikan anak dan juga menantu. Terjadinya peristiwa ini, hanyalah merupakan takdir semata. Terimalah dengan penuh tawakkal. Semoga kebahagiaan senantiasa meliputi kalian."

Singkat cerita, Panji Bayan Sangge pun akhirnya mengawini bidadari itu. Tetapi selama berumah tangga, mereka tak pernah berbicara. Demikianlah, kehidupan mereka berlangsung beberapa lama sampai mereka memperoleh seorang anak.

Karena telah lama kawin, namun tidak pernah mendengar satu patah kata pun dari isterinya, Panji Bayan Sangge menjadi penasaran. Berbagai akal telah dicoba agar isterinya mau berbicara. Dan, sebab-sebabnya pun selalu diselidiki, mengapa ia membisu. Satu hal yang selalu menarik perhatian Panji Bayan Sangge, ialah apabila isterinya akan mengambil air ke sumur. Sebelum berangkat ia selalu masuk ke dalam rumah. Setelah itu barulah pergi ke sumur. Apa gerangan maksudnya? Ada apa di dalam rumah? Hal inilah yang ingin diketahui oleh Panji Bayan Sangge. Barangkali dengan mengetahui latar belakang peristiwa ini dia akan dapat mengetahui mengapa isterinya selalu membisu.

Pada suatu hari ketika selesai makan dan segalagalanya sudah dikembalikan ke tempatnya, ia memperhatikan apa yang akan dilakukan oleh isterinya. Benar juga. Isterinya masuk ke dalam rumah. Tak berapa lama, lalu keluar lagi dan pergi mengambil air ke sumur. Setelah diperkirakan isterinya sampai di sumur, yang letaknya agak jauh dari rumah itu, Panji Bayan Sangge masuk ke dalam rumah.

Setelah beberapa lama memperhatikan apa yang ada di dalam rumah, perhatian Panji Bayan Sangge tertuju kepada segulungan tikar. Ia segera membuka gulungan tikar itu. Dan apa yang didapatinya? Ia menemukan sebuah selendang yang tergulung dan sengaja disembunyikan di tempat itu. Selendang itu bernama Lempot Umbaq yang tak pernah dilepaskan oleh isterinya, kecuali pada waktu mengambil air. "Ada apa dengan selendang ini?" demikian pikirannya.

Dia yakin bahwa selendang itu sangat besar artinya bagi isterinya. "Kalau selendang ini kusembunyikan mustahil, isteriku tak akan menanyakannya. Dalam kesempatan itulah nanti aku akan berbicara dengannya."

Maka, Lempot Umbaq itu disembunyikan di tempat lain. Setelah itu, Panji Bayan Sangge berpurapura sibuk dengan pekerjaannya. Beberapa saat kemudian isterinya kembali dari sumur. Panji Bayan Sangge memperhatikan terus secara diam-diam apa yang akan dilakukannya. Setelah air ditaruh pada tempatnya, isterinya segera naik ke dalam rumah. Bukan main terkejutnya bidadari itu, karena Lempot Umbaq yang tadi ditaruh di bawah gulungan tikar sudah tak ada lagi di tempatnya. Ia tertegun dan berpikir sejenak. Kemudian, ia mencari ke setiap sudut di dalam rumah itu. Namun yang dicari tidak ditemukan.

Ia lalu keluar rumah. Dengan liar serta pandangan tajam ia terus mencari. Air matanya sudah tak dapat ditahan lagi. Ia mencari sambil menangis. Melihat itu, Panji Bayan Sangge mendekat sambil menegur isterinya, "Apa yang sedang kau cari isteriku? Bolahkah aku mengetahuinya? Barangkali aku dapat membantumu."

Isterinya diam. Tak ada jawaban. Sikapnya tetap seperti sedia kala. Namun Panji Bayan Sangge tak berputus asa. Ia bertanya lagi, "Cobalah katakan apa yang sedang kau cari isteriku! Mungkin aku dapat menolongmu. Atau mungkin tak percaya pada diriku?"

Kali ini pun isterinya masih tetap membisu seribu bahasa. Tak sepatah kata pun keluar dari mulutnya, hanya air mata yang terus mengalir. Panji Bayan Sangge bertanya lagi, "Telah beberapa kali kukatakan padamu. Katakanlah dengan sebenarnya, apakah yang sedang kau cari. Aku bersedia membantumu untuk menemukan kembali."

Pada saat itulah isterinya menjawab dengan singkat. Dia hanya mengatakan "Lempot Umbaq". Setelah berkata demikian, ia seketika menghilang tanpa bekas. Semua berlangsung dalam hitungan detik. Tak ada yang mengetahui ke mana perginya. 
Kejadian itu membuat Panji Bayan Sangge menjadi bingung. Ia bingung memikirkan nasib isterinya yang tiba-tiba menghilang. Demikian pula nasib bayi yang ditinggalkan. Tidak terpikir olehnya ke mana harus disusukan. Dan, ke mana pula ia harus mencari dan meminta bantuan. Ia menunggu hingga tujuh hari, tetapi isterinya tidak muncul juga. Akhirnya ia berkata dalam hati, "Ah, bila aku hanya berpangku tangan, tak mungkin isteriku kembali. Dan anakku pasti akan mati. Lebih baik aku mencari upaya, supaya isteriku dapat kubawa kembali."

Setelah berpikir lama, akhirnya Panji Bayan Sangge memutuskan untuk meninggalkan rumah dan mencari isterinya. Kepada Inaq Bangkol, ia berkata, "Ibu, sekarang ananda akan menyerahkan anakku ini kepada ibu. Ananda akan mencari upaya, agar isteriku dapat kubawa kembali. Entah ke mana ananda belum tahu dengan pasti. Mungkin berhasil, mungkin pula tidak. Ananda pasrahkan kepada Yang Maha Kuasa. Tetapi kelak bila anak ini dewasa, sedangkan ananda tak kembali, beritahukanlah siapa orang tuanya yang sebenarnya. Oleh karena itu doa restu ibu sangat ananda harapkan."

Mendengar keinginan anak angkatnya itu, Inaq bangkol sangat terkejut dan bersedih hati. Ia sayang kepada anaknya, terlebih-lebih cucu angkatnya yang masih bayi itu. Namun, untuk menghalangi maksud Panji Bayan Sangge rasanya tidak mungkin lagi. Dengan perasaan berat ia melepaskannya sambil memanjatkan doa ke hadirat Tuhan Yang Maha Kuasa semoga anaknya tetap dalam lindungan dan maksud perjalanannya dapat tercapai.

Setelah ditinggalkan, Inaq Bangkol merasa sedih. Selain itu, ia pun bingung tak tahu harus berbuat apa untuk menyusui cucunya. Ketika Inaq Bangkol sedang kebingungan itu, tiba-tiba ia mendengar suatu suara. "Hai, Inaq Bangkol, bila kamu ingin melihat cucumu itu selamat dan dapat menyusu pada dirimu sendiri, aku akan memberi petunjuk yang harus kau patuhi. Ambil dan gosokkan sekujur tubuhmu dengan daun ini. Sesudah itu peras dan minumlah airnya."

Mendengar suara itu Inaq Bangkol segera mengambil daun yang tiba-tiba jatuh di hadapannya dan melaksanakan petunjuk dari suara gaib yang telah didengarnya. Dan, Air susu segera memancar dari kedua payudaranya. Akhirnya, sang cucu sudah dapat minum air susu kembali.

Sementara itu, Panji Bayan Sangge yang sedang dalam usaha mencari isterinya, telah lama berjalan dan terus berjalan tanpa suatu arah yang pasti sampai akhirnya ia berada di tengah-tengah hutan. Di hutan itu Panji Bayan Sangge kemudian duduk bersila untuk bersemedi. Setelah beberapa lama bersemedi, tiba-tiba ia mendengar suara gaib. "Hai, Panji Bayan Sangge, kalau kamu akan mencari isterimu kamu harus mempersiapkan syaratnya. Kamu harus mendapatkan merang yang berasal dari ketan hitam. Merang ini harus kamu bakar di atas sebuah batu. Sewaktu asapnya mengepul ke udara, lompatilah merang itu. Maka kamu akan menjumpai isterimu. Tetapi jangan kau bingung bila berhadapan dengan banyak perempuan yang rupanya sangat mirip dengan isterimu. Oleh karena itu, kamu kuberikan seekor lalat emas yang ditaruh di dalam sebuah kota emas pula. Kalau kesulitan dalam menentukan yang mana isterimu, lepaskanlah lalat ini. Di mana lalat ini hinggap dan tidak berpindah lagi, itulah isterimu."

Setelah suara itu hilang, ia sadar kembali dan pikirannya dapat dipulihkan. Ketika itu ia pun segera mencari dan menyiapkan merang ketan hitam yang diperlukan sebagai syarat untuk bertemu dengan isterinya. Dengan tidak membuang waktu lagi, ia pun menaiki sebuah batu besar dan dibakarnyalah merang ketan hitam itu. Saat asap merang mulai mengepul ke udara, ia pun melompat. Dan, ketika berada di tengah-tengah asap, seketika itu juga ia membumbung tinggi ke udara, menuju suatu tempat yang tak dapat dijangkau oleh manusia. Bersamaan dengan habisnya asap merang itu tibalah ia pada suatu tempat yang ajaib sekali. Di hadapannya berdiri sebuah istana yang megah, dikelilingi tembok yang kokoh. Tatkala ia berada di dekatnya tiba-tiba pintu gerbang istana itu terbuka sendiri.

Panji Bayan Sangge kemudian memasuki gerbang istana itu. Sebelum memasuki bangunan istana, ia harus melewati halaman yang sangat luas. Saat berjalan di halaman itu, ia melihat seorang laki-laki paruh baya sedang duduk di Berugaq Sekapat. Lakilaki itu menegur, "Hai, orang muda, dari mana asalmu. Apa pula maksud kedatanganmu ke mari? Siapa yang membawamu, hingga berada di tempat ini?"

Dengan hormatnya Panji Bayan Sangge menjawab, "Maaf paman, kedatanganku kemari memang sengaja, untuk menyusul isteriku."

Dengan terkejut, laki-laki itu bertanya, "Menyusul isterimu? Mana mungkin. Tak seorang pun dari anak-anakku pernah kawin. Jangankan kawin, keluar istana ini pun tak pernah. Berkatalah yang sebenarnya, jangan mengada-ada. Siapa yang memberi petunjuk, siapa yang mengatakan padamu dan di mana pula kamu pernah menjumpai anakku? Cobalah ceritakan kepadaku!"

Panji Bayan Sangge tetap menjawab dengan sikap yang pasti, "Dalam petunjuk sudah jelas, bahwa isteriku berada di tempat ini. Tak mungkin berada di tempat lain. Saya yakin benar bahwa isteriku pasti berada di tempat ini."

Orang tua itu berkata, "Sekarang aku akan keluarkan semua anak-anakku. Cobalah engkau 
tunjukkan nanti, yang manakah kau anggap sebagai isterimu. Tetapi harus diingat, apabila nanti kau tak dapat menunjukkan dengan tepat kau harus mempertanggung jawabkan perbuatanmu."Saya sanggup," kata Panji Bayan Sangge.

Maka lelaki tua itu pun mengeluarkan anakanaknya yang berjumlah sembilan orang. Mereka didudukkan berderet, berhadapan dengan Panji Bayan Sangge. Agak bingung juga Panji Bayan Sangge melihat mereka yang semuanya sebaya dan mempunyai wajah yang hampir sama pula. Namun akhirnya ia dapat menguasai diri. Ia ingat akan kotak serta lalat emas yang terdapat di dalam sakunya. Dengan diam-diam kotak itu dibukanya. Lalat emas itu pun keluar lalu terbang di antara semua wanita yang berderet itu dan akhirnya hinggap di dada salah seorang di antara mereka. Sesudah lalat itu diam dan tidak berpindah lagi, maka Panji Bayan Sangge telah mengetahui yang mana isterinya. Dengan penuh kepastian Panji Bayan Sangge menunjuk salah seorang di antara kesembilan bidadari itu.

Laki-laki tua itu kemudian bertanya, "Dari mana kau dapat mengetahui bahwa dia itu adalah isterimu?"

Panji Bayan Sangge pun memberikan keterangan tentang kegunaan lalat yang dibawanya. Lalu katanya, "Lalat itu hinggap di dada isteri saya. Karena mencium bau amis yang keluar dari susunya, karena dia telah melahirkan seorang putera yang kini sedang diasuh oleh ibu saya."

"Di mana kau memperoleh lalat itu?" tanya orang tua itu selanjutnya.

"Lalat itu diberikan oleh sebuah suara gaib ketika saya sedang bersemedi dalam mencari upaya untuk menemukan kembali isteri saya ini."

"Nah, bila demikian halnya baiklah. Aku percaya sekarang. Tak ada hal lagi yang aku ragukan. Pertemuan kalian ini rupanya memang sudah menjadi suratan takdir. Tuhan telah menjodohkan kalian. Sekarang apa sebab kamu ditinggalkan oleh isterimu? Pernahkah kalian dahulu berbicara sewaktu kalian berkeluarga?"

“Tak sekali jua pun," jawab Panji Bayan Sangge.

Jawaban ini makin menambah keyakinan orang tua itu, bahwa anak muda yang ada di hadapannya itu memang benar menantunya. Lalu orang tua itu memberikan keterangan selanjutnya. "Begini anakku, isterimu selalu membisu, disebabkan karena isterimu mengetahui bahwa dia belum memenuhi persyaratan. Persyaratan itu belum pernah dilakukan. Sekarang di tempat ini akan kita penuhi persyaratan itu. Adapun syarat itu ialah apa yang sering disebut dengan nama Umbaq Lempot. Syarat inilah yang dahulu dibutuhkan oleh isterimu. Di sinilah sekarang kita buat untukmu. Dan, inilah yang harus dilakukan oleh keturunanmu kelak. Cara membuatnya ialah dengan motif Ragi Saja (nama motif kain tenun Sasak). Jadi nama lengkap syarat itu adalah Umbaq Lempot Ragi Saja. Nah inilah kebutuhan utama untuk memenuhi hidup di dunia."

Beberapa hari setelah Umbaq Lempot Ragi Saja selesai dibuat, Panji Bayan Sangge dan isterinya pun turun ke bumi. Mereka tiba di tempat yang sama ketika Panji Bayan Sangge membakar merang ketan hitam. Dari tempat itu, mereka kemudian pulang ke rumah orang tua angkat Panji Bayan Sangge untuk berkumpul lagi dengan putera mereka yang sudah lama ditinggalkan.

Setelah Panji Bayan Sangge bersama dengan isterinya kembali ke rumah, puteranya yang diberi nama Mas Panji Pengendeng pun sudah agak besar. Karena ibunya adalah seorang bidadari, maka Mas Panji Pengendeng tidak hanya tampan, melainkan juga mempunyai kekuatan-kekuatan tertentu yang membuatnya sakti mandraguna.

Singkat cerita, beberapa tahun kemudian, setelah Mas Panji Pengendeng itu menjadi dewasa, ia meminta izin kepada kedua orang tuanya untuk membuat dan menempati desa baru, yaitu Desa Selong Semoyong. Sebelum putera tunggalnya itu pergi, kedua orang tuanya memberitahukan syaratsyarat agar dapat hidup di dunia dengan aman dan sentosa, yaitu dengan membuat Umbaq Lempot. Selain itu, ada lagi syarat lain yang harus dilaksanakan, yaitu harus mendirikan sebuah Barugaq Sekepat. Pada Barugaq Sekepat inilah akan hadir para leluhur tatkala ada kegiatan-kegiatan atau upacara sedang dilakukan.

Setelah Mas Panji Pengendeng telah lama menetap di Desa Selong Semoyong dan telah beranak-pinak, terjadilah peperangan di Kerajaan Kelungkung di Pulau Bali. Sebelumnya Raja Klungkung pernah mendapat berita bahwa di bumi Selaparang terdapat seorang ksatria perkasa. Yang dimaksud tidak lain adalah Mas Panji Pengendeng sendiri. Maka dibuatlah surat oleh Raja Klungkung, meminta Mas Panji Pengendeng bersedia membantunya untuk menghadapi musuh.

Ketika undangan dibaca oleh Mas Panji Pengendeng, ia merasa malu jika tidak memenuhi undangan Raja Klungkung itu. Akhirnya undangan itu pun diterima dengan baik dan disanggupi bahwa ia akan pergi dan membatu Raja Klungkung. Keberangkatannya ke Kerajaan Klungkung itu tidak hanya membawa pasukan tentara atau laskar biasa, tetapi disertai juga oleh bala samar sebanyak empat puluh empat.

Setelah tiba di Klungkung dan disambut langsung oleh Raja, maka tanpa membuang waktu lagi ia minta ditunjukkan lokasi peperangan dan langsung maju berperang. Di tengah-tengah peperangan yang 
sedang berkecamuk, nasib malang menimpa Mas Panji Pengendeng yang terkenal sakti mandra guna serta sukar dicari tandingannya itu. Ia terjatuh akibat kakinya tersandung oleh dodotnya sendiri yang bermotif Benang Dua Ragi Poleng (nama motif kain tenun Sasak). Karena malu, ia kemudian memerintahkan para bala samarnya untuk menggotongnya keluar dari medang perang dan langsung kembali ke Lombok tanpa memberitahukan terlebih dahulu kepada Raja Klungkung.

Namun, saat sampai di tanah Lombok ia tidak pulang ke Selong Semoyong, tetapi menuju Gawah Toaq. Setelah tiga hari berada di Gawah Toaq, ia pun memerintahkan bala samarnya agar pergi ke Selong Semoyong untuk memberitahukan keluarganya.

Setelah berita itu tiba di Selong Semoyong, keluarganya sangat terkejut dan panik. Mereka lalu mempersiapkan semua kebutuhan, dan segera berangkat menuju Gawah Toaq. Saat seluruh keluarga telah berada di Gawah Toaq, mereka meminta agar Mas Panji Pengendeng bersedia dibawa pulang ke Selong Semoyong. Dan, kemauan keluarga ini dipenuhi Mas Panji Pengendeng. Mereka pun berjalan beriringan meninggalkan Gawah Toaq menuju Selong Semoyong.

Tatkala rombongan tiba di daerah Embung Puntiq, kondisi Mas Panji Pengendeng kelihatan makin parah. Mas Panji Pengendeng berkata, "Sebaiknya kita beristirahat di sini. Aku sudah terlalu payah dan mungkin tak dapat sampai ke Selong Semoyong. Oleh karena itu mendekatlah kemari semua anak-anakku dan yang lainnya.

Dengarkan baik-baik. Seandainya nanti aku meninggal dunia di tempat ini, kuminta janganlah jenazahku dimakamkan ataupun dibakar. Agar kelak bila ada anak cucuku ingin menziarahiku, mereka terbebas dari perasaan enggan. Biarlah agar semua orang dapat berkunjung ke tempat ini. Bila mereka datang menziarahiku, hendaklah mereka berkeliling sekurang-kurangnya satu kali. Boleh juga dilakukan tiga, lima, tujuh ataupun sembilan kali. Maksudnya supaya anak cucuku yang bergama Islam kelak dapat meniatkan diri belajar tawaf di Mekkah. Juga aku pesankan pada kalian agar mengunjungi sekurangkurangnya dua kali dalam setahun. Yaitu menjelang musim penghujan, ketika bibit padi sudah mulai disiapkan. Dan kedua, sewaktu menanam padi telah selesai.

Melalui tempat inilah kalian memohon kepada Yang Maha Kuasa agar selalu diberikan rahmat-Nya. Dan, janganlah membawa alat-alat pecah belah. Tempat ini adalah hutan. Kalau kalian terjatuh akan menimbulkan kerugian. Cukuplah dengan membawa takilan saja. Lauk pauknya janganlah mewah. Yang penting kalian tetap datang ke tempat ini pada waktu yang telah kusebutkan tadi. Satu hal lagi yang terlarang bagimu kemari adalah mamakai kain sebangsa Ragi Poleng, karena penderitaanku ini akibat tersandung dodot Benang Dua Ragi Poleng dalam peperangan di Klungkung."

Selesai mengucapkan wasiat itu, Mas Panji Pengendeng meminta disiapkan tempat tidur. Ia ingin beristirahat karena merasa lukanya bertambah parah. Setelah tenda dan tempat tidurnya siap, Mas Panji Pengendeng dipapah dan dibaringkan di situ. Beberapa saat kemudian, para pengiring mengira bahwa Mas Panji Pengendeng sedang tidur dengan pulasnya. Mereka tidak menyadari bahwa junjungannya itu telah tiada. Mas Panji Pengendeng telah meninggalkan dunia yang fana ini dan segera menghadap Tuhan.

Pagi harinya, setelah tahu bahwa Mas Panji Pengendeng telah wafat, seluruh rombongan menjadi panik. Mereka tidak tahu apa yang harus dilakukan terhadap jenazah Mas Panji Pengendeng. Akan dibawa kembali ke Selong Semoyang, tak mungkin karena wasiat sudah digariskan lain. Sampai siang hari mereka bingung tak tentu apa yang harus dilakukannya. Tetapi tatkala akan menjenguk jenazah, ternyata jenazah itu tidak ada di tempatnya. Hilang entah ke mana, yang tinggal hanyalah tempat tidurnya saja. Kain penutup jenazah juga tidak ada lagi. Peristiwa ini cocok benar dengan wasit yang telah diberikan. Jenazahnya jangan dikuburkan atau dibakar. Rupanya peristiwa inilah yang dimaksudkan. Maka, oleh masyarakat Selong Semoyang pada tempat di mana Mas Panji Pengendeng meninggal dunia dan akhirnya menghilang dibuat sebuah makam. Dan, makam itu hingga saat ini terkenal dengan nama Makam Embung Puntiq.

\section{Analisis Fungsi Mitos Embung Puntiq Pada Masyarakat Sasak}

Untuk menganalisis fungsi mitos Embung Puntiq pada masyarakat Sasak di desa Sengkerang menggunakan teori yang dikemukakan oleh William R. Bascom yang memiliki empat fungs; (1) sebagai bentuk hiburan, (2) fungsi social, (3) sebagai pendidikan anak-anak (4) sebagai alat pemaksa dan pengawas norma-norma masyarakat dipatuhi oleh anggota kolektifnya.

\section{a. Sebagai bentuk hiburan}

Mitos berkembang dimasyarakat dengan daya tarik utamanya yaitu sebagai hiburan. Masyarakat dapat merasakan mitos, karena untuk menghibur diri dari masalahnya, itulah salah satu sebab mitos dapat terus hidup. 
Sebagaimana mitos Embung Puntik yang dijadikan sebuah hiburan, dikarenakan ketika waktu senggang orang tua menceritakan anakanaknya mengenai kisah tersebut. Karena ceritanya seolah-olrah mereka hidup dalam kisahnya. Yang mengisahkan seorang Raden Panji Bayan tinggal bersama keluarga angkatnya yang dianggap sebagai orang tua kandung. Mereka saling menghormati diceriitakan juga bagaimana kesabaran dan usaha mereka untuk mengatasi berbagai masalah mereka.

\section{b. Sebagai Alat Pendidikan Anak-Anak}

Pendidikan merupakan kebutuhan spiritual yang sangat penting dalam usaha pengembangan kualitas manusia. Untuk itu dituntut usaha untuk melaksanakan pendidikan yang bersifat terus menerus. Pendidikan pada hakikatnya adalah usaha sadar untuk mengembangkan kepribadian atau menanamkan pendidikan pada kepribadian melalui pendidikan di dalam ataupun di luar sekolah dan berlangsung seumur hidup.

\section{SIMPULAN DAN SARAN}

Penelitian yang berjudul "Analisis fungsi dan nilai-nilai budaya mitos Embung Puntiq pada masyarakat Sasak di ddesa Sengkerang Kabupaten Lombok Tengah", ini menjadi salah satu penelitian tentang sastra yang bermamfaat dan bias memberikan tambahan pengetahuan bagi seluruh pembaca dan semoga dapat dijadikan pedoman guna penelitian-penelitian berikutnya.

Khusus yang ditunjukan untuk Pemerintah Kabupaten Lombok Tengah adalah agar lebih mempromosikan Komplekks pemakaman Embung Puntiq sebagai wisata religi Kabupaten Lombok Tengah, sehingga penelitian tenntag mitos Embung Puntiq semakin diminati oleh peneliti. Selain itu, keberadaan kompleks pemakaman tersebut lebih mendapat sorotan dari masyarakat.

Peneliti menyadari bahwa hasil penelitian ini masih jauh dari sempurna karena itulah peneliti mengharapkan agar hasil penelitian ini dapat menjadi pemicu untuk mengembangkan penelitian tentang mitos. Mitos cerita Embung Puntiq hendaknya dilestarikan, karena mitos merupakan asset budaya daerah yang semestinya harus kita jaga dan lestarikan. Sehingga generasi penerus bangsa tidak lupa akan kebudayaan mereka sendiri ditengah-tengah berkembangnya zaman dan masuknya unsur-unsur peradaban modern dunia luar.

\section{REFERENSI}

Astika, I Made. 2014. Sastra Lisan Teori dan Penerepannya. Yogyakarta; gerhana ilmu.

Alwi, Hasan. 2001. 1993. Prosedur Penelitian Suatu Pendekatan Praktek. Jakarta: Bina Aksara.

Basrin. 2014. Analisis Mitos Doro Langguda Dalam Masyarat Desa Sare Ruma Kecamatan Langgudu Kabupaten Bima. FKIP Universitas Muhammadyah: Mataram.

Danandjaya, James. 2002. Faktor Indonesia. Jakarta: pustaka utama graffiti.

Djajasudarma,T.F. 2006. Metode Liguistik Ancongan Penelitian Dan Kajian Bandung: Refika Aditama.

Enderaswara, suwardi. 2006. Filsafat hudup jawa. Tanggerang: cakrawala.

Haris, Abdul. 2015. Analisis fungsi mitus wadu nocu di desa bumi pojo kecamatan donggo kabupaten bima. FIKIP Universitas Muhammadyah: Mataram.

Koentjaranigrat. 1997. Manusia dan Kebudayaan di Indonesia. Jajarta: Djambatan.

Moleong, Lexy J. 2003. Metodologi Penelitian Kualitatif. Bandung. CV Remaja Rosdakarya.

Noor, juliansyah. 2011. Metode Penelitaian Kualitatif. Bandung. CV Remaja Rosdakarya.

Nurgiantoro, Burhan. 2006. Sastra Anak Pengantar Pemahaman Dunia Anak. Yogyakarta;: Gadjah Mada University Press.

Saputra. 2015. Analisis Mitos Temba Romba Pada Masyarakat Sumi Kecamatan Lambu Kabupaten Bima.

Peursen, Van. 1976. Strategi Kebudayaan. Jakarta: Kanisius.

Proop. 1972. Teori Sastra. Yogyakarta: Bentang Pustaka.

Ratna, N.K. 2011. Antropologi Sastra. Yogyakarta: Pustaka Pelajar. 